\title{
Comparative proteomics to investigate the in vitro antiproliferative effect of dietary polyphenols against K562 leukemia cells
}

\author{
[Gıda kaynaklı polifenollerin K562 lösemi hücreleri üzerine in vitro çoğalmayı \\ önleyici etkisinin karşılaştırmalı proteomik çalışmalarla incelenmesi]
}

\author{
Mustafa Çelebier ${ }^{1,2}$, \\ Carolina Simón, \\ Sacide Altınöz ${ }^{2}$, \\ Alejandro Cifuentes ${ }^{1}$
}

\author{
${ }^{1}$ Laboratory of Foodomics, CIAL, CSIC, Nicolas \\ Cabrera 9, Madrid, Spain \\ ${ }^{2}$ Hacettepe University, Faculty of Pharmacy, \\ Department of Analytical Chemistry, \\ Ankara, Turkey
}

\begin{abstract}
Objective: The lack of success with classical targeted therapies in cancer treatment has forced researchers to employ either combined therapies or agents that interfere with multiple pathways.In this study, a proteomic evaluation was performed to understand the in vitro antiproliferative effect of dietary compounds against leukemia cells in proteome level. Typical human cell models of leukemia (i.e., wild K562 cells and multi-drug resistant leukemia cells K562/R) were treated with rosemary (Rosmarinus officinalis L.) extracts rich in polyphenols and a comparative proteomic study was performed to identify up- or down-regulated proteins by in vitro antiproliferative effect of polyphenols.

Methods: The protein fraction from the polyphenol-treated and control K562 and K562/R cells were separated through two dimensional polyacrylamide gel electrophoresis (2DE) and their proteomic profiles compared by image analysis. The proteins identified to be overexpressed or underexpressed in K562 and K562/R cells after the polyphenol treatment were identified by MALDI-TOF/TOF MS.

Results: The results in this study were evaluated to understand the mode of action of these dietary constituents against leukemia cell proliferation. Dietary polyphenols extracted from rosemary bring about the up regulation or down regulation of different proteins on leukemia cells. These proteins are related to tumorigenesis, cancer proliferation and antioxidant activity.

Conclusion: Our results revealed that the studied rosemary extract rich in polyphenols induced the down regulation of adenine phosphoribosyl transferase and annexin A1 in K562/R cell lines and tubulin alpha-1C chain in K562 cell lines. According to the expression proteomics results in this study, it could be concluded that the rosemary polyphenols shows in vitro antiproliferative activity in K562 and K562/R leukemia cell lines.
\end{abstract}

Key Words: Foodomics, Proteomics, 2-DE Electrophoresis, Leukemia, Rosemary polyphenols, MALDI-TOF

Conflict of Interest: The authors have no conflict of interest.

\section{ÖZET}

Amaç: Kansere karşı bugüne kadar bilinen tedavi yöntemlerinin eksiklikleri araştırmacıları kombine tedavi yöntemlerine veya birden fazla metabolik yolağı etkileyen ajanlarla tedaviye yönlendirmiștir. Bu çalıșmada, proteomik bir yaklaşım sergilenerek gıda kaynaklı bileșiklerin lösemi hücrelerine karşı in vitro çoğalmayı önleyici etkisi proteom düzeyinde açıklanmaya çalışılmıştır. Lösemi hücre hatları (wild tip (K562) ve coklu ilaç dirençli (K562/R) lösemi hücre hattı) biberiyeden (Rosmarinus officinalis L.) elde edilen polifenollerce zengin ekstrelerle muamele edilmiştir. Karşılaştırmalı proteomik çalışmalar yapılarak polifenollerin in vitro çoğalmayı önleyici etkisiyle düşük veya yüksek miktarda ifade edilen proteinler tanımlanmıştır.

Metod: K562 ve K562/R hücre hatlarının biberiyeden elde edilen polifenollerle işlem görmüş grubu ve kontol grubuna ait protein fraksiyonları 2 boyutlu poliakrilamid jel elektroforezle (2DE) ayrılmış ve proteomik profilleri imaj analiz çalışmaları ile karșıllaştııılmıştır. Biberiye ile ișlem sonrası K562 ve K562/R hücre hatlarında yüksek veya düşük miktarda ifade edildiği tespit edilen proteinler belirlenmiş ve MALDI-TOF/TOF MS ile analiz edilerek tanımlanmıştır.

Bulgular: Bu çalışmadan elde edilen sonuçlar, gıda kaynaklı yapı taşlarının lösemi hücrelerinin çoğalmasına karşı etki mekanizmasının anlaşılması yönünde değerlendirilmiştir. Biberiyeden elde edilen ekstrelerdeki polifenoller lösemi hücre hatlarındaki bazı proteinlerin yüksek veya düşük miktarda ifade edilmesine sebebiyet vermektedir ve bu proteinler tümör gelişimi, kanserin yayılması ve antioksidant aktivite ile ilgili proteinlerdir.

Sonuç: Elde edilen sonuçlar göstermektedir ki; polifenolce zengin biberiye ekstreleri ile işlem görmüs gruplarda K562/R hücre hattı için adenin fosforibosil transferaz ve aneksin A1 düșük miktarda ifade edilirken, K562 hücre hattı içinse tübülin alfa-1C düşük miktarda ifade edilmiştir. Kiyaslamalı proteomik çalıșmalar sonucunda polifenollerce zengin biberiyenin, K562 ve K562/R kanser hücrelerinin çoğalmasını önlemede in vitro düzeyde etkili olduğu gösterilmiştir.

Anahtar Kelimeler: "Foodomics", Proteomik, 2-DE Elektroforez, Lösemi, Biberiye polifenolleri, MALDI-TOF

Çıkar Çatışması: Yazarların çıkar çatışması yoktur. 


\section{Introduction}

Despite the advances in the understanding of the pathophysiology of cancer, the current treatment regimens for cancer show limited survival chances for most advanced stage cancers, since these treatments primarily target tumor bulk but not cancer stem cells $[1,2]$. In this sense major efforts to delay the process of carcinogenesis and to reduce the morbidity and mortality of cancer are being carried out. All the traditional cancer therapies including surgery, hormonal therapy, anti-angiogenesis therapy, chemotherapy, immunotherapy, etc. show a lack of efficacy in long-term outcome because of their failure to target cancer stem cells and toxicity due to non-specific effects on normal cells [3]. In addition to conventional therapeutic drugs, numerous natural dietary constituents have shown promising effects in cancer tumor suppression [4]. On the other hand, a number of epidemiological studies have been carried out attempting to correlate high dietary phenolic compounds and flavonoid intake, through the consumption of fruits and vegetables, with reduced risk of cancer [5-8]. The importance of polyphenol intake in reducing the risk of cancer has repeatedly been claimed through different dietary interventions [912]. Polyphenols are known to act in signal transduction pathways related to cellular proliferation, differentiation, apoptosis, inflammation, angiogenesis and metastasis [9].

Mediterranean herb rosemary (Rosmarinus officinalis L.) has been associated with a variety of health benefits [13]. Among the active constituents of rosemary, phenolic diterpenes and triterpenes have been the subject of intense research due to their potential benefits for human health $[14,15]$. In addition to their strong antioxidant properties, rosemary extracts rich in phenolic diterpenes and triterpenes have been also of interest for their anti-inflammatory and anticancer activities [15].

Recently, a global concept called Foodomics, based on the integration of "omics" approaches, has been introduced by our group [16] for a comprehensive evaluation of the health benefits of dietary constituents [17]. One of the main purposes in this type of studies is to improve our limited understanding of the roles of nutritional compounds at the different levels of genomic expression (mRNA, protein, metabolite). In previous work, we observed that carnosol and carnosic acid-enriched extracts from rosemary exerted significant antiproliferative activity on human leukemia cells [18]. In that work, transcriptomic analysis revealed several sets of differentially expressed genes that may be involved in relevant biological functions in cancer cells. As a representative example, inhibition of myelocytomatosis oncogene (MYC) transcription factor function by rosemary polyphenols was found interesting because of its importance in cell proliferation. Also, a significant transcriptional induction of several antioxidant and detoxifying genes (OSGIN1 and NQO1) was involved in the response of leukemia cells to rosemary polyphe- nols. Moreover, metabolomics analysis indicated that increased glutathione levels in treated-leukemia cells with polyphenol-rich extract was linked to the observed antiproliferative effect [18]. For a deeper knowledge of the molecular mechanisms underlying the antiproliferative effect of a rosemary extract rich in phenolic diterpenes (mainly, carnosic acid and carnosol), a proteomic study was performed in this work. Since proteins are the carrier of life activities and the major executors of the functions of genes, proteomic studies play also an important role in prevention, diagnosis and treatment of cancer [19-21]. Direct evaluation of the proteins expressed in tumor cells offers information that cannot be obtained by the study of DNA alterations or RNA expression pattern. In most cases, although studies of differential mRNA expression are informative, they do not always correlate with protein concentrations because the proteome is dynamic and keeps changing even in the same cell type at the different stages of activity or development. Moreover, proteins are often subject to proteolytic cleavage or posttranslational modifications that cannot be detected by genome analysis [22-24]. Thus, in the present work, a proteomic study was performed, and the effect of rosemary polyphenols in two human leukemic cell lines K562 (one showing a drug-sensitive phenotype, and another exhibiting a drugresistant phenotype), was studied. A combination of twodimensional polyacrylamide gel electrophoresis (2DE), combined with mass spectrometry (MS), advanced image analysis and bioinformatics-based protein database searches, was used for this purpose.

\section{Materials and Methods}

\section{Chemicals and reagents}

All chemicals were of analytical reagent grade. MilliQ water was from Milli-Q system (Millipore, Bedford, MA, USA). Acetone, trichloroacetic acid (TCA) and DL-Dithiothreitol (DTT) were from Sigma-Aldrich (St. Louis, MO, USA), Merck (Whitehouse Station, NJ, USA) and Fluka (Buchs, Switzerland), respectively. Urea and 3-[(3-cholamidopropyl)dimethylammonio]-1-propanesulfonate (CHAPS) were from Sigma-Aldrich. Bio-Lyte 3/10 Ampholyte, mineral oil, bromophenol blue used on isoelectric focusing were from Bio-Rad (Hercules, CA, USA). Glycerol (30\% ultrapure) used on preparing equilibrium buffers was from Bio-Rad. Tributhylphosphine (TBP) and iodoacetamide (IAA) from Sigma-Aldrich were used as reduction and alkylation agents, respectively. SYPRO ${ }^{\circledR}$ Ruby protein gel stain used for gel staining was from Bio-Rad.

\section{Buffers and solutions}

Phosphate buffered saline (PBS) solution (138 mM sodium chloride, $2.7 \mathrm{mM}$ potassium chloride and $10 \mathrm{mM}$ sodium hydrogen phosphate, at $\mathrm{pH}$ 7.4) used for cell washing and homogenization buffer $(10 \mathrm{mM}$ Tris- $\mathrm{HCl}, 5$ mM EDTA, $120 \mathrm{mM} \mathrm{NaCl}$, at pH 7.4) used in cell dis- 
ruption process were from Sigma-Aldrich. For protein precipitation, 10\% TCA and $20 \mathrm{mM}$ DTT in acetone was prepared. Sample buffer for solubilization of precipitated proteins contains $8 \mathrm{M}$ urea, 2\% CHAPS, $50 \mathrm{mM}$ DTT, $0.2 \%$ Bio-Lyte $3 / 10$ ampholyte and $0.001 \%$ bromophenol blue. Equilibration buffer 1 (375 mM Tris-HCl (pH 8.8), $6 \mathrm{M}$ urea, $2 \%$ SDS and $5 \mathrm{mM}$ TBP) and equilibration buffer 2 (375 mM Tris- $\mathrm{HCl}$ ( $\mathrm{pH} 8.8$ ), $6 \mathrm{M}$ urea, $2 \% \mathrm{SDS}$ and $135 \mathrm{mM}$ IAA) were used prior to the SDS-PAGE second dimension. Agarose solution (containing 0.5\% low melt agarose, 1x Tris-glycine-SDS buffer, 0.001\% bromophenol blue) used to fix the IPG strips at the top of the polyacrylamide gels was from Bio-Rad. For SDS-PAGE step, Criterion XT MOPS buffer from Bio-Rad was used as running electrolyte.

\section{Rosemary extract}

Extracts rich in dietary polyphenols were obtained from rosemary (Rosmarinus officinalis L.) using supercritical fluid extraction (SFE) under the following conditions of pressure and solvent: supercritical $\mathrm{CO}_{2}$ plus $7 \%(\mathrm{v} / \mathrm{v})$ ethanol at 150 bar and $40^{\circ} \mathrm{C}$ for $30 \mathrm{~min}$, as reported previously [17]. Chemical characterization of this extract provided information on the major phenolic constituents, namely cirsimaritin, genkwakin, carnosol, carnosic acid and methylcarnosate [25].

\section{Cell culture}

Human erythroleukemia K562 cell line obtained from ATCC (American Type Culture Collection, LGC Promochem, UK) and a daunomycin (DNM)-resistant K562/R cell subline were grown in DMEM supplemented with $5 \%$ heat-inactivated fetal calf serum, $2 \mathrm{mM}$ of Lglutamine, $50 \mathrm{U} \mathrm{mL}^{-1}$ of penicillin $\mathrm{G}$ and $50 \mu \mathrm{g} \mathrm{mL}^{-1}$ of streptomycin, at $37^{\circ} \mathrm{C}$ in humidified atmosphere by applying $5 \% \mathrm{CO}_{2}$. Cells were plated at a density of 10000 cells $\mathrm{cm}^{-2}$ in $60-\mathrm{mm}$ diameter culture plates. Triplicate samples for each leukemia cell line were incubated without rosemary polyphenols (control group), and with $5 \mu \mathrm{M}$ of total rosemary polyphenols (treated group), for $48 \mathrm{~h}$.

\section{Cell viability and cell cycle}

To verify the previous results on the effect of rosemary polyphenols on cell growth [18] cell viability in K562 and K562/R cell lines was measured by counting total and nonviable cells with ADAM Cell Counter (Digital-Bio, Korea) technology based on a fluorescent microscopy technique with a sensitive CCD camera.

From the cellular distribution pattern of DNA, the induced apoptosis by the treatment of the cells with the phenolic extract was measured by determining the amount of apoptotic cells in the sub-G1 peak by flow cytometry in an Epics XL instrument (Beckman Coulter, Miami, FL, USA).

\section{Sample collection}

Control and treated group cells were washed with PBS solution. After centrifugation, the pellet was resuspended with homogenization buffer and protease inhibitor cock- tail containing 4-(2-aminoethyl)benzenesulfonyl fluoride, pepstatin A, E-64, bestatin, leupeptin, and aprotinin from Sigma Aldrich. Cells were disrupted with a Poly$\operatorname{tron}^{\circledR}$ homogenizer Capitol Scientific (Austin, TX, USA) and centrifuged for $14 \mathrm{~min}$ at $14000 \mathrm{~g}\left(\right.$ at $\left.4^{\circ} \mathrm{C}\right)$. After the pellet (nuclear fraction) had been discarded, the supernatant was centrifuged for $1 \mathrm{~h}$ at $10000 \mathrm{~g}$ (at $4^{\circ} \mathrm{C}$ ) and kept at $-80^{\circ} \mathrm{C}$ temperature (cytosolic fraction), in which the samples could be safely stored without continuing enzymatic activity.

\section{Total protein quantification}

The total protein amount was determined by using DC protein assay from Bio-Rad. Bovine serum albumin was used as standard and diluted with homogenization buffer-water (50:50, v/v) in a range between 0.2-1.5 mg/ $\mathrm{mL}$, while the collected samples were diluted with water $(50: 50 \mathrm{v} / \mathrm{v})$. Absorbances of standards and samples were measured at $750 \mathrm{~nm}$ by using PowerWave Microplate Spectrophotometer XS (Winooski, VT, USA).

\section{D-PAGE analysis}

Samples (cytosolic fraction) were desalted following a protein precipitation procedure using cold $\left(-20^{\circ} \mathrm{C}\right)$ acetone with $10 \%(\mathrm{v} / \mathrm{v})$ TCA and $20 \mathrm{mM}$ DTT. Protein pellets from all samples were solubilized in "sample buffer" to a final concentration of $1 \mathrm{mg} \mathrm{mL}^{-1}$. Each 11-cm long IPG strip pH 5-8 (Bio-Rad) was rehydrated with $280 \mu \mathrm{L}$ of protein solution for $4 \mathrm{hrs}$. Isoelectric focusing (IEF) was carried out with a Protean IEF Cell (Bio-Rad) using following steps: (i) 1,000 V, 4 hours; (ii) 8,000 V, 2.5 hours; (iii) $8,000 \mathrm{~V}, 50,000 \mathrm{Vh}$; (iv) 8,000 V-1,000 V, $68000 \mathrm{Vh}$ by using a Protean IEF Cell unit from Bio-Rad. After IEF process the strips were subjected to a 2-step equilibration for 10 minutes (each) by using "equilibration buffer 1 " and "equilibration buffer 2 " under gentle shaking. The IPG strips were then laid on a Criterion XT Precast Gel 4-12\% Bis-Tris (IPG 1 Well Comb, $11 \mathrm{~cm}, 1.0 \mathrm{~mm}$ ) with $0.5 \%$ agarose in the cathode buffer (Criterion XT MOPS Buffer (1x) from Bio-Rad). Precision plus protein unstained standard was used as marker on SDS-PAGE. Criterion XT MOPS Buffer (1x) from Bio-Rad was also used as running buffer. The electrophoretic run was performed by applying a constant voltage of $100 \mathrm{~V} /$ gel through a PowerPac ${ }^{\mathrm{TM}}$ Universal Power Supply from Bio-Rad until the dye front reached the bottom of the gel. Gels were incubated in a fixing solution containing $7 \%$ acetic acid and $10 \%$ methanol for 48 hours followed by Sypro staining. Gels were stained by gentle shaking overnight. After this time gels were washed in a washing solution containing $7 \%$ acetic acid and $10 \%$ methanol for a few seconds prior to image acquisition. The 2-DE gels were scanned with a Versa-Doc image system (Bio-Rad). Image analyses were performed by using PDQuest 2-D analysis software (version 8.0) from Bio-Rad. After filtering the gel images for removing the background, spots were automatically detected and manually edited (if necessary). PDQuest 2-D 


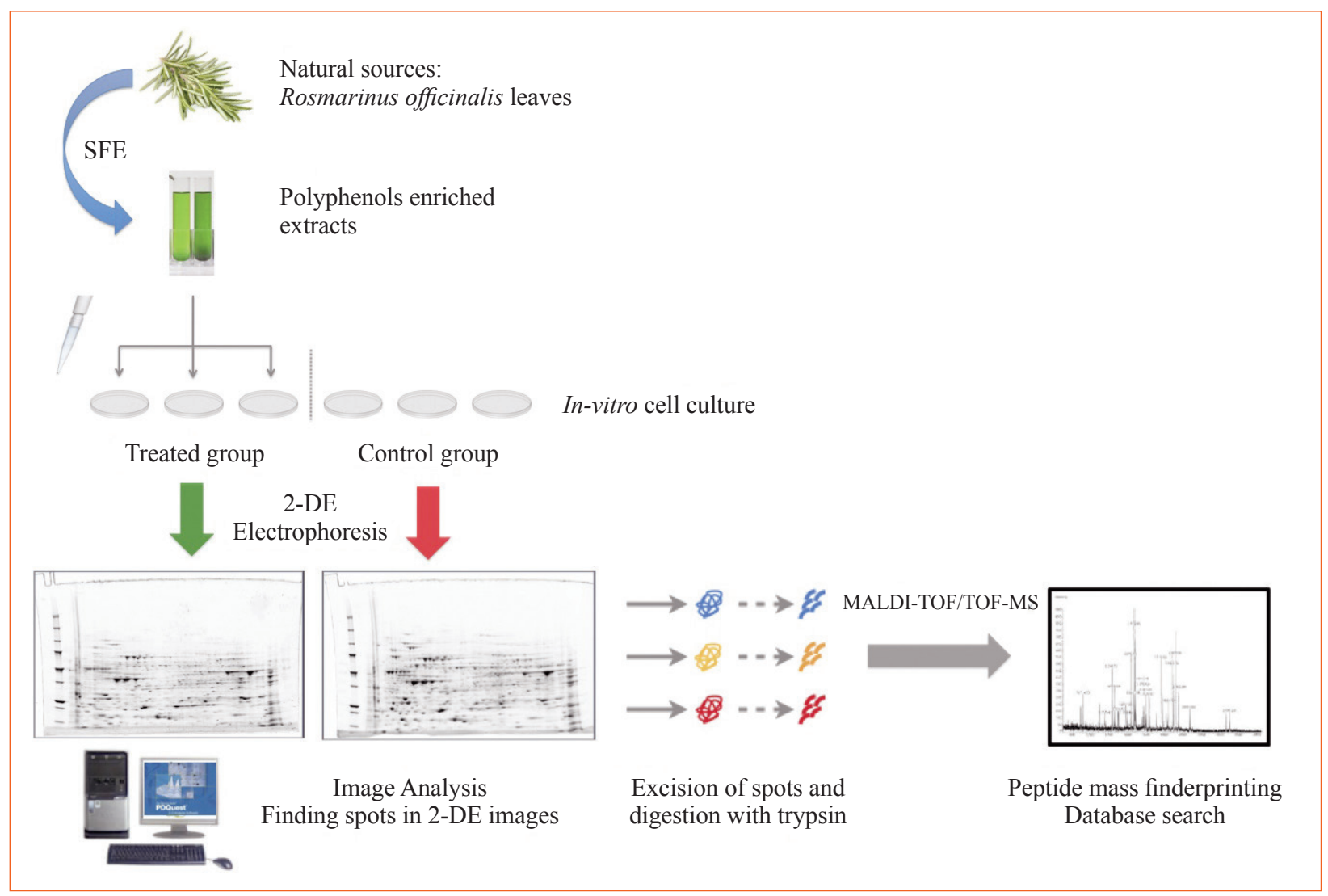

Figure 1. Expression proteomics on K562 and K562/R cancer cell lines treated with polyphenols.

analysis software was also used for comparative analyses and selection of the up- or down-regulated proteins after polyphenol treatment. Relative comparison of the intensity abundance between control and treated cells was performed using Student's t-test. Significantly differentially expressed protein spots with more than 2-folds increased or decreased intensity $(\mathrm{p}<0.05)$ as observed in all replicate gels were scored were subjected to further analysis.

Two groups were defined in PDQuest software. The first group was the proteins statistically identical in the same group according to their spot intensities and the second group was the proteins having 2-fold between the groups (control and treated). The intersection of these two groups was the proteins that we focused. Spots with a p-value of less than 0.05 and an average change greater than 2-fold were considered as statistically significant regulated spots and subjected to identification.

\section{In-gel protein digestion}

Selected spots were excised manually, deposited in 96well plates and processed automatically in a Proteineer DP (Bruker Daltonics, Bremen, Germany). Gel spots were washed firstly with $200 \mu \mathrm{L} 50 \mathrm{mM}$ ammonium bicarbonate and secondly with $200 \mu \mathrm{L} \mathrm{ACN}$ prior to reduction with $10 \mathrm{mM}$ DTT in $25 \mathrm{mM}$ ammonium bicarbonate solution. Alkylation was carried out with $55 \mathrm{mM}$ IAA in $50 \mathrm{mM}$ ammonium bicarbonate solution. Gel spots were then rinsed with $200 \mu \mathrm{L} 50 \mathrm{mM}$ ammonium bicarbonate followed by $200 \mu \mathrm{L}$ ACN. Finally gel plugs were dried under a stream of nitrogen. Trypsin (sequencing grade, Promega, Madison, WI) at a final concentration of $16 \mathrm{ng}$ $\mathrm{mL}^{-1}$ in $25 \% \mathrm{ACN} / 50 \mathrm{mM}$ ammonium bicarbonate solution was added and the digestion took place at $37{ }^{\circ} \mathrm{C}$ for $6 \mathrm{~h}$. The reaction was stopped by adding $0.5 \%$ TFA for peptide extraction. The eluted tryptic peptides were dried by speed-vacuum centrifugation and were resuspended in $4 \mu \mathrm{L}$ of MALDI solution. A $0.8 \mu \mathrm{L}$ aliquot of each peptide mixture was deposited onto a 386-well OptiTOFTM Plate (Applied Biosystems, Framingham, MA, USA) and allowed to dry at room temperature. A $0.8 \mu \mathrm{L}$ aliquot of $3 \mathrm{mg} \mathrm{mL}^{-1}$ CHCA ( $\alpha$-cyano-4-hydroxycinnamic acid) in MALDI solution was then deposited onto the dried digest and allowed to dry at room temperature.

\section{Peptide mass fingerprinting}

For MALDI-TOF/TOF MS analysis, spectra were automatically acquired on an ABI 4800 MALDI-TOF/TOF MS (Applied Biosystems, Framingham, MA, USA) in positive ion reflector mode (the ion acceleration voltage was $25 \mathrm{kV}$ to MS acquisition and $1 \mathrm{kV}$ to MS/MS) and the obtained data were stored into the ABi 4000 Series Explorer Spot Set Manager. To submit the combined peptide mass fingerprinting (PMF) and MS/MS data to MASCOT software v.2.2.04 (Matrix Science, London, UK), GPS Explorer v4.9 was used, searching in the non-redundant NCBI protein database (NCBI no. $20100930(11,960,556$ 


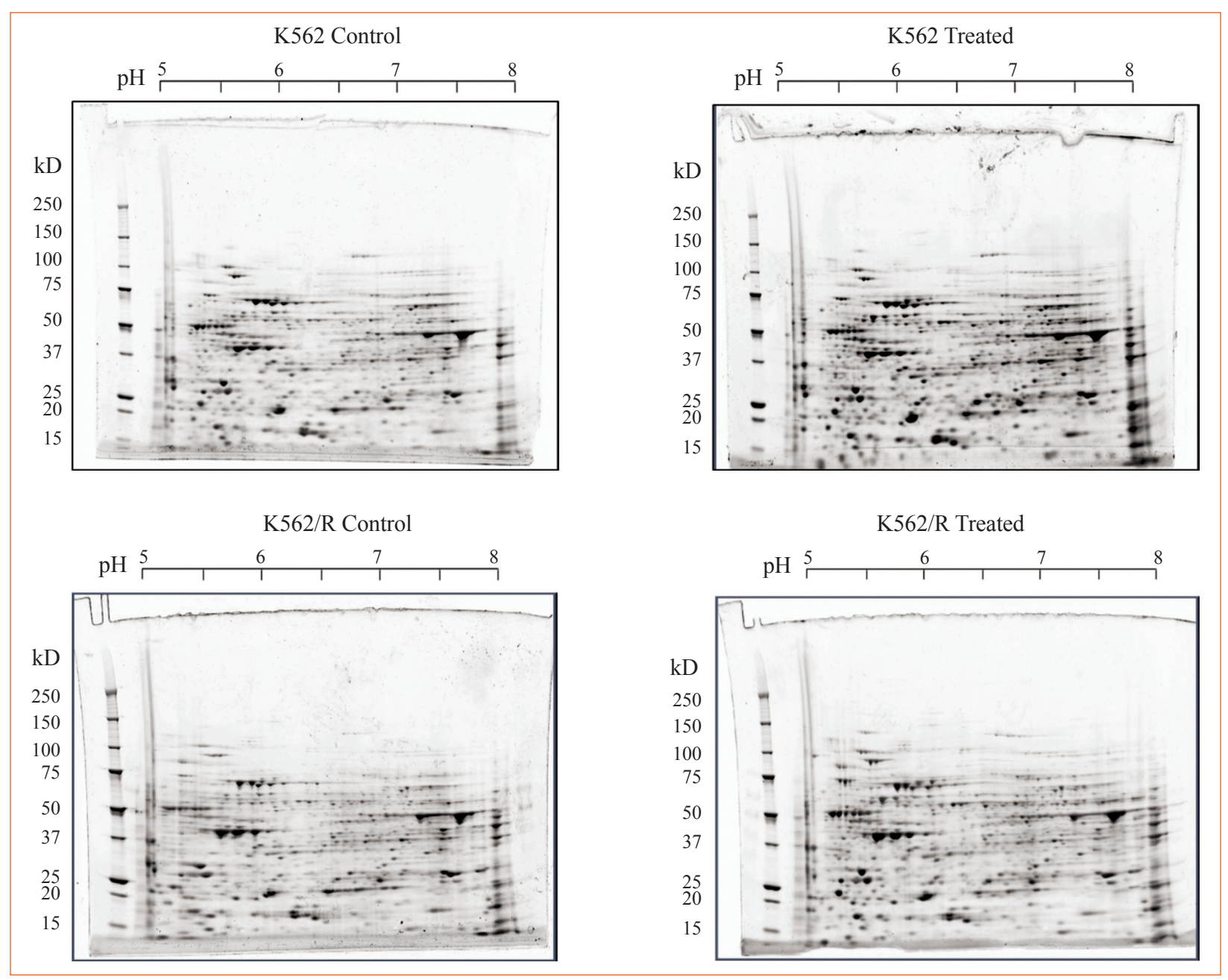

Figure 2. Control and treated cells for K562 and K562/R cell lines.

sequences; 4,082,908,561 residues)). The confidence interval for protein identification was set to $\geq 95 \%(p<0.05)$ and only peptides with an individual ion score above the identity threshold were considered as correctly identified.

\section{Results and Discussion}

\section{Proteomic analysis}

The effect of dietary polyphenols against K562 and $\mathrm{K} 562 / \mathrm{R}$ cancer cell lines was investigated to elucidate the molecular mechanisms that could explain their antiproliferative action. The K562 and K562/R cancer cell lines treated with rosemary polyphenols were separated by $2 \mathrm{DE}$ electrophoresis compared with the control groups (the same cell lines not-treated) through expression proteomics. For that purpose 2DE for protein separation was combined with MS analysis and database search to identify differentially expressed proteins. Figure 1 shows the experimental summary performed in this study.

Protein patterns of control and treated K562 and K562/R cells in Sypro-stained gels are given in Figure 2. The PDQuest 8.0 program could detect an average of 350 and 347 resolved spots in K562 and K562/R cancer cells, respec- tively. Treatment with rosemary extract caused several changes in protein expression. The overexpressed and underexpressed protein spots (with an average change greater than 2-fold and a p-value $<0.05$ ) after treatment with polyphenols were selected and analysed by MALDITOF/TOF MS.

For K562 leukemia cells, 1 protein was underexpressed and 17 proteins were overexpressed by the polyphenol treatment, while 8 proteins were underexpressed and 5 proteins were overexpressed after the polyphenol treatment of K562/R leukemia cells (Table 1). The representative protein patterns of K562 and K562/R cancer cells are shown in Figure 3.

The selection for the identification of the overexpressed or underexpressed proteins was performed according to their fold change values. The mostly changed proteins (according to the image analysis results) were identified through MALDI-TOF/TOF-MS for K562 and K562/R cell lines. The proteins overexpressed or underexpressed were manually excised and analysed by MALDI-TOF/ TOF MS.

Total number of 6 proteins in K562 and 10 proteins in 
Table 1. The summary of the proteomic study on K562 and K562/R cell lines

\begin{tabular}{lccccc}
\hline Cell Line & $\begin{array}{c}\text { Total spots } \\
\text { identified } \\
\text { through image } \\
\text { analysis }\end{array}$ & $\begin{array}{c}\text { Underexpressed } \\
\text { proteins } \\
2 \text {-fold } \\
\mathrm{p}<0.05\end{array}$ & $\begin{array}{c}\text { Overexpressed } \\
\text { proteins } \\
2 \text {-fold } \\
\mathrm{p}<0.05\end{array}$ & $\begin{array}{c}\text { Identified proteins } \\
\text { through } \\
\text { MALDI-TOF/TOF-MS* }\end{array}$ & $\begin{array}{c}\text { Proteins mainly } \\
\text { linked to tumorigenesis, } \\
\text { cancer proliferation } \\
\text { and antioxidant activity** }\end{array}$ \\
\hline K562 & 350 & 1 & 17 & 6 & 5 \\
K562/R & 347 & 8 & 5 & 10 & 7 \\
\hline
\end{tabular}

*Spots $\uparrow 4805$ for K562 and spots $\uparrow 4712$, $\downarrow 6411$ and $\downarrow 7302$ for K562/R seem to be related with contamination and their identification is therefore not provided **Spots $\downarrow 3604, \uparrow 3607, \uparrow 4601, \uparrow 5602$, and $\uparrow 8639$ for K562; spots $\downarrow 3108, \downarrow 7219, \downarrow 7431, \uparrow 2714, \uparrow 2610, \uparrow 0812$, and $\uparrow 4611$ for K562/R cell lines.

Table 2. Proteins up -or down- regulated in wild leukemic cells (K562) after the polyphenol treatment

\begin{tabular}{lccc}
\hline Spot & Spot ID & $\begin{array}{c}\text { Proteins underexpressed after the treatment } \\
\text { IR/IC* }\end{array}$ & Description \\
\hline 1 & 3604 & 0.04 & Tubulin alpha-6 chain (Alpha-tubulin 6) \\
\hline Spot & Spot ID & Proteins overexpressed after the treatment \\
IR/IC* & Description \\
\hline 3 & 3607 & 7.57 & $60 \mathrm{kDa}$ heat shock protein, mitochondrial [Homo sapiens] \\
4 & 4601 & 5.29 & $60 \mathrm{kDa}$ heat shock protein, mitochondrial [Homo sapiens] \\
5 & 5602 & 3.58 & $60 \mathrm{kDa}$ heat shock protein, mitochondrial [Homo sapiens] \\
* Ratio of the intensity of protein spots. IC: control group; IR: treated group.
\end{tabular}

*Ratio of the intensity of protein spots. IC: control group; IR: treated group.

Table 3. Proteins up -or down- regulated in multi-drug resistant leukemic cells (K562/R) after the polyphenol treatment

\begin{tabular}{|c|c|c|c|}
\hline \multicolumn{4}{|c|}{ Proteins underexpressed after the treatment } \\
\hline Spot & Spot ID & IR/IC* & Description \\
\hline 1 & 3108 & 0.29 & $\begin{array}{l}\text { Adenine phosphoribosyltransferase isoform a } \\
\text { [Homo sapiens] }\end{array}$ \\
\hline 2 & 7219 & 0.41 & Chain A, Crystal Structure Of Hgstp1-1[v104] \\
\hline & & & Complexed With The Gsh Conjugate Of (+)-Anti-Bpde \\
\hline 3 & 7431 & 0.49 & Annexin A1 [Homo sapiens] \\
\hline \multicolumn{4}{|c|}{ Proteins overexpressed after the treatment } \\
\hline Spot & Spot ID & IR/IC* & Description \\
\hline 4 & 2714 & 6.58 & $60 \mathrm{kDa}$ heat shock protein, mitochondrial [Homo sapiens] \\
\hline 5 & 2610 & 5.28 & $60 \mathrm{kDa}$ heat shock protein, mitochondrial [Homo sapiens] \\
\hline 6 & 0812 & 4.22 & $\begin{array}{l}78 \mathrm{kDa} \text { glucose-regulated protein precursor } \\
\text { [Homo sapiens] }\end{array}$ \\
\hline 7 & 4611 & 3.02 & Retinal dehydrogenase 2 isoform 1 [Homo sapiens] \\
\hline
\end{tabular}

K562/R cancer cell lines were identified through peptide mass fingerprinting. However, likely some contamination took place during the analysis. Namely, spots 4805 for K562 and spots 4712, 6411 and 7302 for K562/R seem to be related to this contamination due to the fact that they are not involved in homo sapiens or they are not able to be predicted truly according to the MALDI-TOF/
TOF-MS results. Their identification is therefore not provided below.

The identified proteins through peptide mass fingerprinting are shown in Table 2 and Table 3 . After protein identification it was observed that their functions were mainly linked to tumorigenesis, cancer proliferation and antioxidant activity. The MS spectra of some of them (Annexin 


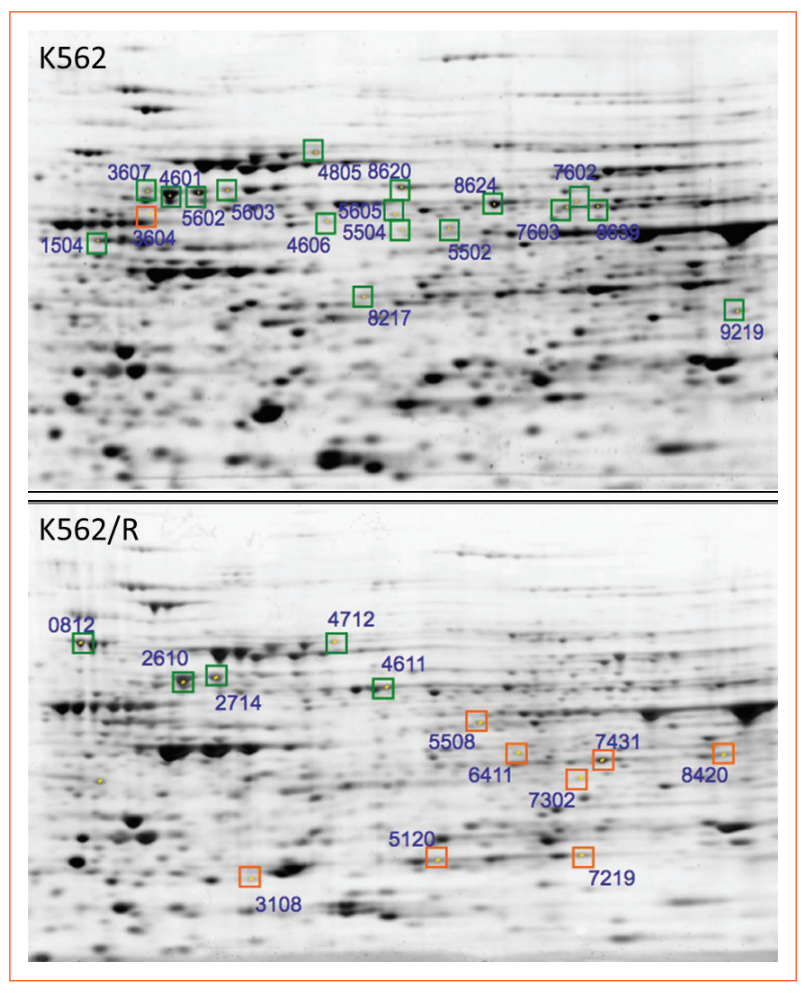

Figure 3. The proteomic pattern of K562 and K562/R cells (spots marked as green show proteins overexpressed in treated groups and marked as red show underexpressed in polyphenol-treated groups).

A1, Retinal dehydrogenase 2 isoform 1, Tubulin alpha-6 chain, and D-3-phosphoglycerate dehydrogenase) are given in Figure 4. The biological roles of identified proteins are further discussed below.

Adenine phosphoribosyl transferase (UniPort ID: G5E9J2) is an enzyme with transferase activity involved in the pu- rine nucleotide salvage pathway. A salvage pathway is a pathway in which nucleotides (purine and pyrimidine) are synthesized from intermediates in the degradative pathway for nucleotides [26]. Salvage pathways are used to recover bases and nucleosides that are formed during degradation of RNA and DNA [27]. It functions as a catalyst in the reaction between adenine and phosphoribosyl pyrophosphate to form adenosine monophosphate [27,28]. It was observed that adenine phosphoribosyl transferase in K562/R cancer cells was down-regulated after the polyphenol treatment, which could explain the anti-proliferative effect of rosemary polyphenols on these cancer cells. Retinal dehydrogenase 2 (UniPort ID: O94788) belongs to the family of oxidoreductases. Retinal dehydrogenase 2 is up-regulated in K562/R cancer cells after the polyphenol treatment probably as a result of their pro-antioxidative effect. Heat shock proteins (HSP) are overexpressed in a wide range of human cancers and are implicated in tumor cell proliferation, differentiation, invasion, metastasis, death, and recognition by the immune system [29-31]. The HSPs could be used either as an anticancer agent alone or in combination with tumor antigens, or as target for antichaperone compounds [32]. Since the HSP60 proteins are known to be considerably up-regulated on cancer tissues in comparison to the normal tissues [33], the up-regulation of $60 \mathrm{kDa}$ heat shock proteins (UniPort ID: P10809) in both K562 and K562/R cell lines by the rosemary polyphenol treatment was looked like an unexpected result in first impression. Even though it is well known that HSP60 expression is increased in leukemia [34], in recent years, there are some new knowledge about particularly HSP60 proteins. As it is indicated, some of the newly identified functions of HSP60 are associated with carcinogenesis, specifically with tumor cell survival and proliferation.

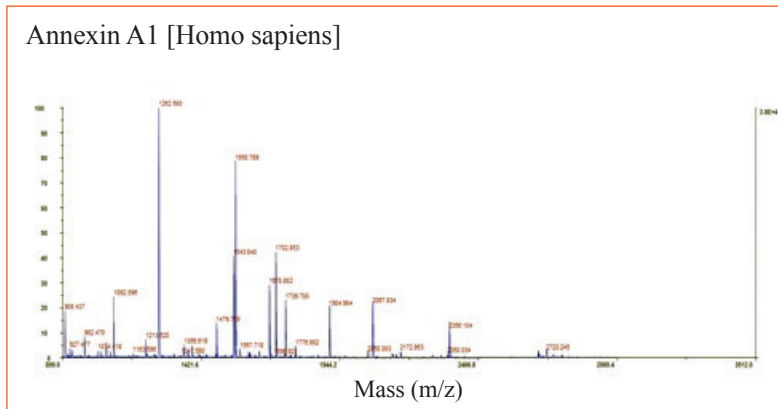

Retinal dehydrogenase 2 isoform 1 [Homo sapiens]

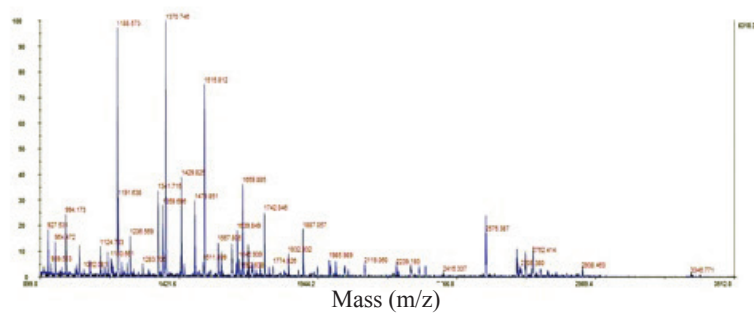

Tubulin alpha-6 chain (Alpha-tubulin 6)

D-3-phosphoglycerate dehydrogenase [Homo sapiens]
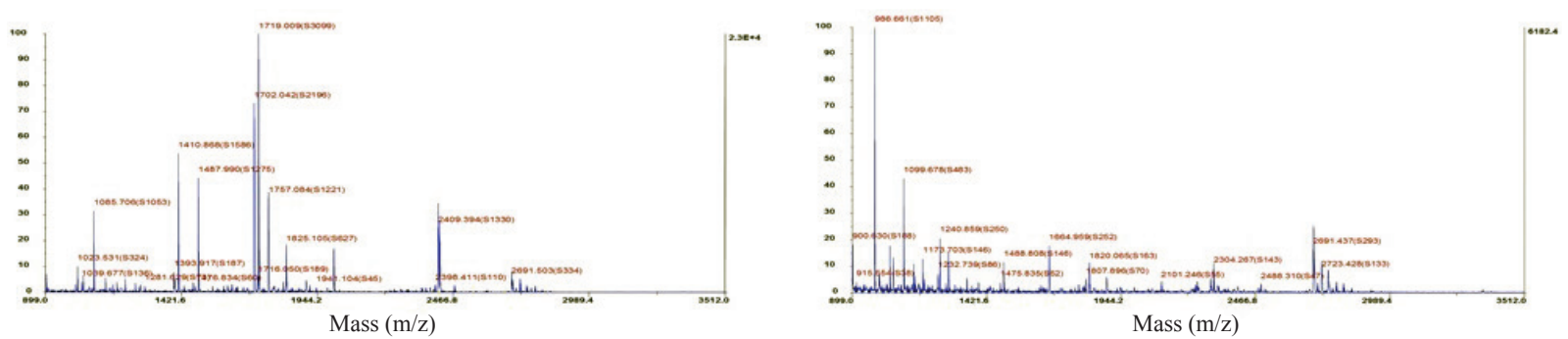

Figure 4. MS spectra of annexin A1, retinal dehydrogenase 2 isoform 1, tubulin alpha-6 chain, and D-3-phosphoglycerate dehydrogenase. 
Thus, assessing the levels of HSP60 in tumor cells and in sera of cancer patients is becoming an attractive area of investigation aiming at the development of means for practical applications in clinical oncology. Since HSP60 participates in extracellular molecular interactions and cell signaling and also in key intracellular pathways of some types of tumor cells, the idea of using HSP60 in anti-cancer therapy (chaperonotherapy) should be investigated. In another study, it was also noted that HSP60 could be used to enhance antitumor immunity [35]. Therefore, the upregulation of especially HSP60 proteins (as seen in Table 2 and 3) except other HSPs could be evaluated in different ways, but it is an open subject matter to be discussed and it is pointed out by that way in this study. Besides HSP60, another stress protein, annexin A1 (UniPort ID: P04083) [36], was down-regulated as expected by the polyphenol treatment. There is good evidence that in certain clinical conditions, changes in annexin expression levels or localisation may contribute to the pathological consequences and sequelae of disease. In this way, annexins are indirectly linked to one of the most serious human disease cancer [37]. For example, it is reported that Annexin-1 protects MCF7 breast cancer cells against heat-induced growth arrest and DNA damage [38]. As it is indicated, Annexin 1 is involved in a variety of inflammatory pathways, on cell proliferation machinery, in the regulation of cell death signaling, in phagocytic clearance of apoptosing cells, and most importantly in the process of carcinogenesis [39]. Therefore, it could be a potential target for novel therapeutic intervention in a host of disease states. Since, it is overexpressed in many cancer types and it is possible to simply diagnose of hairy cell leukaemia by detection of annexin A1 [40-42], the down regulation of annexin A1 through polyphenol treatment could be concluded as the antiproliferative effect of dietary polyphenols on K562 cell lines. Tubulin alpha-1C chain (UniPort ID: Q9BQE3) is a member of tubulin which is one of several members of a small family of globular proteins. Tubulin, having $\alpha / \beta$ heterodimer forms, is the constituent subunit of microtubules. Microtubules are important in cellular processes such as mitosis, intracellular transport and cell motility. The critical role that microtubules play in cell division makes them a very suitable target for the development of chemotherapeutic drugs against the rapidly dividing cancer cells [43]. Some of the anti-tumor drugs such as taxanes and vinca alkaloids target tubulin in cancer chemotherapy $[44,45]$. In light of foregoing, inhibition of cancer cell proliferation after treating with extracts might be expressed through the interaction of rosemary compounds with Tubulin alpha1C chain. D-3-phosphoglycerate dehydrogenase (UniPort ID: O43175) catalyzes the transition of 3-phosphoglycerate into 3-phosphohydroxypyruvate, which is the first and rate-limiting step in the phosphorylated pathway of serine biosynthesis [46]. D-3-phosphoglycerate dehydrogenase is required for serine biosynthesis, a precursor of nucleotide biosynthesis [47] and its activity is increased in human colon carcinoma and indirectly involved in promoting cancer progression [47-49]. Suppression of D-3-phosphoglycerate dehydrogenase in cell lines with elevated D-3-phosphoglycerate dehydrogenase expression causes a strong decrease in cell proliferation and a reduction in serine synthesis [50]. However, it is reported that the tamoxifen, an antagonist of the estrogen receptor, induces D-3-phosphoglycerate dehydrogenase in breast cancer cells [51]. In this study, we also observed the upregulation of D-3-phosphoglycerate dehydrogenase after the polyphenol treatment of K562 cancer cell lines. This remarkable effect after polyphenol treatment will be further studied to correlate it with the observed cell proliferation suppression.

\section{Conclusions}

Accumulating evidence has demonstrated the potential therapeutic activity of plant polyphenolic compounds in human malignancies, including cancer. Moreover, different phytochemicals can also synergize with other compounds to produce antiproliferative effects. In this sense, new insight on the biological mechanisms involved in the antiproliferative properties of dietary constituents in cancer cells, has been presented. The present study provides novel evidence that dietary polyphenols extracted from rosemary bring about the up and down regulation of different proteins on leukemia cells. These proteins were found to be related to tumorigenesis, cancer proliferation and antioxidant activity. Our results revealed that the studied rosemary extract rich in polyphenols induced the down regulation of adenine phosphoribosyl transferase and annexin A1 in K562/R cell lines and tubulin alpha-1C chain in K562 cell lines. The up-regulation of D-3-phosphoglycerate dehydrogenase after polyphenol treatment of K562 cancer cell lines was an unexpected result and it could be studied further to be correlated with anticancer activity. The workflows that have been described in this work are a helpful starting point to understand mechanisms of the processes involved in antiproliferative activities of rosemary polyphenols in cancer in-vitro model. Further work is needed to demonstrate the potential benefit of specific bioactive components from rosemary, dose-dependent antiproliferative effects, and synergistic or antagonistic effect of rosemary components in complex extracts.

\section{Acknowledgement}

Mustafa Çelebier thanks to The Council of Higher Education, Turkey for his grant. This work was supported by AGL2008-05108-C03-01 (Ministerio de Ciencia e Innovación, Spain).

\section{Conflict of Interest}

There are no conflicts of interest among the authors.

\section{References}

[1] Reya T, Morrison SJ, Clarke MF, Weissman IL. Stem cells, cancer, and cancer stem cells. Nature 2001; 414(6859):105-11. 
[2] Jones RJ, Matsui WH, Smith BD. Cancer stem cells: are we missing the target? J Natl Cancer Inst 2004; 96(8):583-5.

[3] $\mathrm{Hu} \mathrm{Y,} \mathrm{Fu} \mathrm{L.} \mathrm{Targeting} \mathrm{cancer} \mathrm{stem} \mathrm{cells:} \mathrm{a} \mathrm{new} \mathrm{therapy} \mathrm{to} \mathrm{cure}$ cancer patients. Am J Cancer Res 2012; 2(3):340-56.

[4] Manson MM, Gescher A, Hudson EA, Plummer SM, Squires MS, et al. Blocking and suppressing mechanisms of chemoprevention by dietary constituents. Toxicol Lett 2000; 112-113:499-505.

[5] Romagnolo DF, Selmin OI. Flavonoids and cancer prevention: a review of the evidence. J Nutr Gerontol Geriatr 2012; 31(3):206-38.

[6] Arts IC. A review of the epidemiological evidence on tea, flavonoids, and lung cancer. J Nutr 2008; 138(8):1561-6.

[7] Le Marchand L. Cancer preventive effects of flavonoids--a review. Biomed Pharmacother 2002; 56(6):296-301.

[8] Ahmed FE. Effect of diet, life style, and other environmental/ chemopreventive factors on colorectal cancer development, and assessment of the risks. J Environ Sci Health C Environ Carcinog Ecotoxicol Rev 2004; 22(2):91-147.

[9] Ramos S. Cancer chemoprevention and chemotherapy: Dietary polyphenols and signalling pathways. Mol Nutr Food Res 2008; 52(5):507-26.

[10] Link A, Balaguer F, Goel A. Cancer chemoprevention by dietary polyphenols: Promising role for epigenetics. Biochem Pharmacol 2010; 80(12):1771-92.

[11] Guo WM, Kong E, Meydani M. Dietary Polyphenols, Inflammation, and Cancer. Nutrition and Cancer-an International Journal 2009; 61(6):807-10

[12] Ibanez C, Simo C, Garcia-Canas V, Gomez-Martinez A, Ferragut JA, et al. CE/LC-MS multiplatform for broad metabolomic analysis of dietary polyphenols effect on colon cancer cells proliferation. Electrophoresis 2012; 33(15):2328-36.

[13] Ngo SN, Williams DB, Head RJ. Rosemary and cancer prevention: preclinical perspectives. Crit Rev Food Sci Nutr 2011; 51(10):946-54.

[14] Johnson JJ. Carnosol: a promising anti-cancer and anti-inflammatory agent. Cancer Lett 2011;305(1):1-7

[15] Skrovankova S, Misurcova L, Machu L. Antioxidant activity and protecting health effects of common medicinal plants. Advances in food and nutrition research 2012; 67:75-139.

[16] Cifuentes A. Food analysis and foodomics. J Chromatogr A 2009; 1216(43):7109.

[17] Herrero M, Simo C, Garcia-Canas V, Ibanez E, Cifuentes A. Foodomics: MS-based strategies in modern food science and nutrition. Mass Spectrom Rev 2012; 31(1):49-69.

[18] Valdes A, Simo C, Ibanez C, Rocamora-Reverte L, Ferragut JA, Garcia-Canas V, Cifuentes A. Effect of dietary polyphenols on K562 leukemia cells: a Foodomics approach. Electrophoresis 2012; 33(15):2314-27.

[19] Wang JJ, Liu Y, Zheng Y, Lin F, Cai GF, et al. Comparative proteomics analysis of colorectal cancer. Asian Pac J Cancer Prev 2012; 13(4):1663-6.

[20] Su AP, Li ZJ, Tiani BL, Cao SS, Zhang Y, et al. Comparative proteomics of pancreatic cancer. [Article in Chinese] Sichuan Da Xue Xue Bao Yi Xue Ban 2011; 42(5):633-7. [Abstract]

[21] Brown KJ, Fenselau C. Investigation of doxorubicin resistance in MCF-7 breast cancer cells using shot-gun comparative proteomics with proteolytic 180 labeling. J Proteome Res 2004; 3(3):455-62.

[22] Li W, Li JF, Qu Y, Chen XH, Qin JM, et al. Comparative proteomics analysis of human gastric cancer. World J Gastroenterol 2008; 14(37):5657-64

[23] Tyers M, Mann M. From genomics to proteomics. Nature 2003; 422(6928):193-7.

[24] Rubporn A, Srisomsap C, Subhasitanont P, Chokchaichamnankit $\mathrm{D}$, Chiablaem $\mathrm{K}$, et al. Comparative proteomic analysis of lung cancer cell line and lung fibroblast cell line. Cancer Genomics Proteomics 2009; 6(4):229-37.

[25] Herrero M, Plaza M, Cifuentes A, Ibanez E. Green processes for the extraction of bioactives from Rosemary: Chemical and functional characterization via ultra-performance liquid chromatography-tandem mass spectrometry and in-vitro assays. J Chromatogr A 2010; 1217(16):2512-20.

[26] Weber G. Enzymes of purine metabolism in cancer. Clinical biochemistry 1983; 16(1):57-63.

[27] Murray AW. The biological significance of purine salvage. Annual review of biochemistry 1971; 40(1):811-26.

[28] Manfredi J, Holmes EW. Purine salvage pathways in myocardium. Annual review of physiology 1985; 47(1):691-705.

[29] Ciocca DR, Calderwood SK. Heat shock proteins in cancer: diagnostic, prognostic, predictive, and treatment implications. Cell Stress Chaperones 2005; 10(2):86-103.

[30] Li Z, Srivastava P. Heat-Shock Proteins. Current Protocols in Immunology 2004: A. 1T. 1-A. 1T. 6.

[31] Sherman M, Multhoff G. Heat shock proteins in cancer. Ann N Y Acad Sci. 2007; 1113:192-201.

[32] Cappello F, de Macario EC, Marasà L, Zummo G, Macario AJ. Hsp60 expression, new locations, functions, and perspectives for cancer diagnosis and therapy. Cancer biology \& therapy 2008; 7(6):801-9.

[33] Ghosh JC, Dohi T, Kang BH, Altieri DC. Hsp60 regulation of tumor cell apoptosis. J Biol Chem 2008; 283(8):5188-94.

[34] Sedlackova L, Spacek M, Holler E, Imryskova Z, Hromadnikova I. Heat-shock protein expression in leukemia. Tumor Biology 2011; 32(1):33-44

[35] Cappello F, Czarnecka AM, La Rocca G, Di Stefano A, Zummo $\mathrm{G}$, et al. Hsp60 and Hsp10 as antitumour molecular agents. Cancer Biol Ther 2007; 6(4):487-9.

[36] Rhee HJ, Kim GY, Huh JW, Kim SW, Na DS. Annexin I is a stress protein induced by heat, oxidative stress and a sulfhydryl-reactive agent. Eur J Biochem 2000; 267(11):3220-5.

[37] Hayes MJ, Moss SE. Annexins and disease. Biochem Biophys Res Commun 2004; 322(4):1166-70.

[38] Nair S, Hande MP, Lim LH. Annexin-1 protects MCF7 breast cancer cells against heat-induced growth arrest and DNA damage. Cancer Lett 2010; 294(1):111-7.

[39] Lim LH, Pervaiz S. Annexin 1: the new face of an old molecule. FASEB J 2007; 21(4):968-75.

[40] Duncan R, Carpenter B, Main L, Telfer C, Murray G. Characterisation and protein expression profiling of annexins in colorectal cancer. Br J Cancer 2008; 98(2):426-33.

[41] Falini B, Tiacci E, Liso A, Basso K, Sabattini E, Pacini R, et al. Simple diagnostic assay for hairy cell leukaemia by immunocytochemical detection of annexin A1 (ANXA1). Lancet 2004; 363(9424):1869-70.

[42] Deng S, Wang J, Hou L, Li J, Chen G, et al. Annexin A1, A2, A4 and A5 play important roles in breast cancer, pancreatic cancer and laryngeal carcinoma, alone and/or synergistically. Oncol Lett 2013; 5(1):107-12.

[43] Zhou J, Giannakakou P. Targeting microtubules for cancer chemotherapy. Curr Med Chem Anticancer Agents 2005; 5(1):65-71.

[44] Owellen RJ, Owens AH Jr, Donigian DW. The binding of vincristine, vinblastine and colchicine to tubulin. Biochem Biophys Res Commun 1972; 47(4):685-91.

[45] Derry WB, Wilson L, Khan IA, Luduena RF, Jordan MA. Taxol differentially modulates the dynamics of microtubules assembled from unfractionated and purified beta-tubulin isotypes. Biochemistry 1997; 36(12):3554-62.

[46] Sugishita H, Kuwabara Y, Toku K, Doi L, Yang L, et al. L-Serine 
regulates the activities of microglial cells that express very low level of 3-phosphoglycerate dehydrogenase, an enzyme for L-Serine biosynthesis. J Neurosci Res 2001;64(4):392-401.

[47] Snell K, Weber G. Enzymic imbalance in serine metabolism in rat hepatomas. Biochem J 1986; 233(2):617-20.

[48] Snell K, Natsumeda Y, Eble JN, Glover JL, Weber G. Enzymic imbalance in serine metabolism in human colon carcinoma and rat sarcoma. Br J Cancer 1988; 57(1):87-90.

[49] Snell K, Natsumeda Y, Weber G. The modulation of serine me- tabolism in hepatoma 3924A during different phases of cellular proliferation in culture. Biochem J 1987; 245(2):609-12.

[50] Possemato R, Marks KM, Shaul YD, Pacold ME, Kim D, et al. Functional genomics reveal that the serine synthesis pathway is essential in breast cancer. Nature 2011;476(7360):346-50.

[51] Al-Dhaheri MH, Shah YM, Basrur V, Pind S, Rowan BG. Identification of novel proteins induced by estradiol, 4-hydroxytamoxifen and acolbifene in T47D breast cancer cells. Steroids 2006; 71(1112):966-78. 